\title{
Biomass allocation and nutrients balance related to the concentration of Nitrogen and Phosphorus in Salvinia auriculata (Salviniaceae)
}

\author{
J. C. C. Medeiros ${ }^{a *}$, F. F. Coelho ${ }^{b}$ and E. Teixeira \\ áLaboratório Ecologia Evolutiva de Plantas Herbáceas, Programa Ecologia Aplicada, Departamento de Biologia, \\ Universidade Federal de Lavras - UFLA, Câmpus Universitário, Caixa Postal 3037, CEP 37200-000, Lavras, MG, Brazil

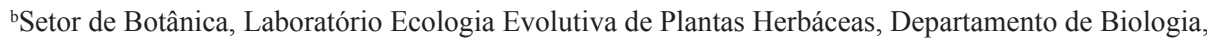 \\ Universidade Federal de Lavras - UFLA, Câmpus Universitário, Caixa Postal 3037, CEP 37200-000, Lavras, MG, Brazil

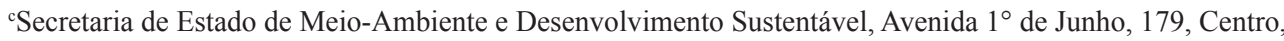 \\ CEP 35500-036, Divinópolis, MG, Brazil \\ *e-mail: jcc-bio@hotmail.com
}

Received: October 8, 2014 - Accepted: February 11, 2015 - Distributed: May 31, 2016

(With 1 figure)

\begin{abstract}
Aquatic plants can use differential allocation (trade-off) of carbon among their structures depending on the nutrition concentration. Given that $\mathrm{N}$ and $\mathrm{P}$ are limiting in the growth of plants, our questions were: Are the $\mathrm{N}$ and $\mathrm{P}$ concentrations in $S$. auriculata related to the biomass allocation to its structures? Is a differential allocation of $\mathrm{N}$ and $\mathrm{P}$ between floating and submerged leaves? We evaluated the relation between the nutrients and the biomass allocation, and the trade-off among the leaves using the Spearman correlation. Our results showed that N and P concentrations in S. auriculata are related to the biomass allocation to its structures, and that there is no trade-off of these nutrients between "shoot and root". Thus, we can see the importance of $\mathrm{N}$ and $\mathrm{P}$ concentration in the biomass of S. auriculata, and why this plant is capable to development in different environments as a weedy.
\end{abstract}

Keywords: nutrients, Salviniaceae, trade-off, resources.

\section{Alocação de biomassa e o Balanço de nutrientes relacionados à concentração de Nitrogênio e Fósforo em Salvinia auriculata (Salviniaceae)}

\begin{abstract}
Resumo
Plantas aquáticas podem realizar alocação diferencial (trade-off) de carbono entre as suas estruturas dependo da disponibilidade de nutrientes. Considerando que $\mathrm{N}$ e P são limitantes para o crescimento de plantas, nossas perguntas foram: As concentrações de $\mathrm{N}$ e $\mathrm{P}$ em $S$. auriculata estão relacionadas com a alocação de biomassa para suas estruturas? Existe alocação diferencial de N e P entre os folíolos aéreos e a "raiz"? Avaliamos a relação entre os nutrientes e a biomassa, e o trade-off entre as folhas utilizando correlação de Spearman. Os resultados encontrados mostram que as concentrações de N e P em S. auriculata estão relacionadas com a alocação de biomassa para as suas estruturas, e que não há um trade-off de N e P entre os folíolos aéreos e a "raiz". Dessa maneira, é possível observar a importância de $\mathrm{N}$ e $\mathrm{P}$ no ganho de biomassa de $S$. auriculata, e porque a espécie é capaz de se desenvolver em diferentes ambientes como uma planta daninha.
\end{abstract}

Palavras-chave: nutrientes, Salviniaceae, trade-off, recursos.

\section{Introduction}

Resource allocation refers to the distribution of carbon, nitrogen and other nutrients among the structures of the organism, where different functions will be performed, such as reproduction (Lovett-Doust, 1989). In plants, resource allocation also reflects the competition for limited resources (Stearns, 1992) and implies in a trade-off, which characterizes the preferential direction of resources towards one function or structure over others (Weiner, 2004). Plants need available energy to perform functions like

growth, reproduction and survival, but when exposed to environmental stress, they can make differential allocations as a functional adjustment to compensate the stress (Sultan, 2000). Most studies do not consider the allocation of critical nutrients, such as $\mathrm{N}$ and $\mathrm{P}$, to growth and reproduction.

Plant nutrition often has an effect on the biomass allocation to the different parts of the plant (Wilson, 1988). Plant species can exhibit a stronger plastic response in carbon allocation between roots and shoots (Grime, 1979; 
Luo et al., 2013), and can present mechanisms to adjust an imbalance of exogenous resources by allocating new biomass to the organs that are involved in acquiring the scarcest resources (Marschener, 1995). The base for most modeling of the balance growth of plants is the optimal allocation of mass to balance root/shoot ratio (Iwasa and Roughgarden, 1984).

Aquatic plants play important functions in their ecosystem, which are related to nutrients cycling and storage (Esteves, 2011; Olson et al., 1999; Gopal, 1990; Madsen et al., 2001; Stansfield et al., 1997; Martín et al., 2005). However, changes in aquatic ecosystems generated by anthropogenic influence (Chapin 3rd. et al., 2004), in addition to environmental seasonality, cause variations in the water nutrient content. This variation can cause eutrophication, the gradual concentration of organic matter and the enrichment of nutrients in aquatic environments (Rast and Thornton, 1996), and, consequently, affects the nutrient uptake by the plants (Jampeetong and Brix, 2009). This phenomenon offers a large amount of resources that favor growth and formation of crowded mats of macrophytes. Infestations of floating macrophytes in this type of environments have been reported to cause serious problems around the world (Camargo et al., 2003; McFarland et al., 2004). Salvinia auriculata is a good example of a free-floating macrophyte that presents vigorous growth in places under favorable conditions, exceeding 200 tonnes ha ${ }^{1}$ in ten days (Julien et al., 2002). This species can totally cover the surface of the water and cause negative impacts in the ecosystem (Jampeetong and Brix, 2009). It is necessary to develop efficient measures to control the extensive growth of Salvinia. To help achieve this, knowledge of its growth and biomass allocation under variable environmental conditions is necessary.

Nutrient storage in aquatic macrophytes varies with a wide range of factors such as climate change, species composition, water level and nutrient availability in the environment. These organisms are restricted by limiting essential elements, such as nitrogen $(\mathrm{N})$ and phosphorus $(\mathrm{P})$, and evolved different mechanisms to obtain those elements for the synthesis of new biomass (Silva, 2010). Studies show that $\mathrm{P}$ is the main nutrient that limits macrophyte and phytoplankton productivity (Huszar et al., 2006), especially in free-floating macrophytes (Camargo et al., 2003). Species of the Salvinia genus present growth rate differences when exposed to different $\mathrm{N}$ sources (Jampeetong and Brix, 2009; McFarland et al., 2004; Jampeetong et al., 2012a). $\mathrm{N}$ and $\mathrm{P}$ assimilation directly affects aquatic macrophyte growth, development and represent key resources for the life of these plants (Bornette and Puijalon, 2011). Besides, these nutrients are the major causes of eutrophication in aquatic ecosystems, leading to significant changes in their structure and functionally (Rast and Thornton, 1996).

The ability of plants to uptake nutrients is different among species. Aquatic plants absorb nutrients through their leaves (Barko and Smart, 1986), while emergent macrophytes obtain $\mathrm{N}$ and $\mathrm{P}$ from the substratum, especially through their roots (Ran et al., 2004). Free-floating macrophytes obtain N and other nutrients directly from the water column through their roots and the underside of their leaves (Cedergreen and Madsen, 2002). In the case of S. auriculata, which produces clonal plants, $\mathrm{N}$ is not translocated only from the root to the shoot, but also through the development of new ramets ( $\mathrm{Li}$ and Wang, 2011).

It is known that aquatic plants have been used as wastewater treatment for their great capacity to remove nutrients in eutrophic waters bodies (e. g., Ellis, et al., 1994; Peterson and Teal, 1996; Panigatti and Maine, 2003; Wolff et al., 2012). Therefore, it is important to understand the relationship between mechanisms of storage of essential nutrients by plants and how they allocate biomass to different plant structures. Studies about the $\mathrm{N}$ and $\mathrm{P}$ concentration in aquatic macrophytes and how relates to growth and biomass allocation can potentially help in the management of these plants. Nevertheless, studies that assess these nutrient concentrations in aquatic fern tissues are scarce.

Thus, the purpose of this study was to measure the $\mathrm{N}$ and $\mathrm{P}$ concentration in the floating and submerged leaves of Salvinia auriculata, and to evaluate if these concentrations are related to the biomass allocation of the plant structures under natural conditions. Based on the following questions: (1) Are the $\mathrm{N}$ and $\mathrm{P}$ concentrations in the plant related to allocation of biomass to reproductive structures (e.g., sporocarps and buds) and to vegetative structures (e.g., floating and submerged leaves)?, (2) Is there a differential allocation of $\mathrm{N}$ and $\mathrm{P}$ between floating and submerged leaves (shoot and root)?. We hypothesized that: (a) The biomass of sporocarp, buds, floating leaves and submerged leaf is related to the higher $\mathrm{N}$ and $\mathrm{P}$ concentration in the plant. (b) A differential allocation of $\mathrm{N}$ and $\mathrm{P}$ occurs between floating leaves and submerged leaf, indicating a trade-off.

\section{Material and Methods}

\subsection{Study area}

The study area is inserted in the Rio Grande basin, sub-basin of the Paraná River, and comprises the states of Minas Gerais and São Paulo in Brazil. We chose three marginal ponds located in the south of Minas Gerais:

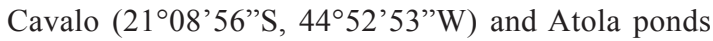
( $21^{\circ} 08^{\prime} 53^{\prime}$ 'S , 4453'59'W), which are influenced by Rio das Mortes, and Jacaré pond ( $21^{\circ} 11^{\prime} 15^{\prime}$ 'S , 45 $\left.05^{\circ} 02^{\prime \prime} \mathrm{W}\right)$ which is influenced by Rio Grande. The three ponds are permanent and the water level fluctuates with rainfall (PORTAL MEIO AMBIENTE, 2014). These ponds usually form crowded mats of $S$. auriculata, which did not change during sampling of specimens throughout the year.

\subsection{Study species}

Salvinia auriculata Aublet, 1775 (Monylophyta: Salviniaceae) is a free-floating fern that can form thick mats on the surface of the water. The plant consists of ramets connected by rhizomes forming matted colonies. Each ramet is comprised of a node bearing two floating 
green leaves and one submerged leaf that functions as a root (Sculthorpe, 1985). The submerged leaf bears the spore-producing organs, which consist of a sori surrounded by an indusium globose ("sporocarp"; De La Sota, 1962). The sporocarps are resistant structures and their production occurs during the dry period, when clonal growth is unfavorable. During flood periods, asexual reproduction is favored by formation of buds. Both reproductive strategies allow the specie to survive in places with seasonal patterns, like temporary ponds that are subject to drought and flood periods (Coelho et al., 2005).

\subsection{Field data and measurements}

We conducted four sample collections in 2012, two in the flood period (February and March) and two during the dry period (August and September) in each pond. Firstly, we collected a sample of water from each pond in all the collections to proceed with analysis of $\mathrm{N}$ and $\mathrm{P}$ concentrations in water. These samples were conducted to a specialized laboratory and the $\mathrm{N}$ concentration in water was determined by means of Kjeldahl semi-micro process, and the $\mathrm{P}$ concentration by colorimetry (APHA, 2005). After that, we collected an amount of ramets to fill a 20L plastic bag, that was used to chemical analysis and to obtain dry biomass. Since the ponds were small, we collected ramets from several points in each pond where the plants were more abundant, and placed them in the bag with pond water.

For the $\mathrm{N}$ and $\mathrm{P}$ plant analyses, after each collection, we washed and selected about 200 ramets or the necessary fresh ramet biomass to obtain exactly $5 \mathrm{~g}$ of dry biomass from each vegetative structure (floating and submerged leaves). The $5 \mathrm{~g}$ of each structure was used to proceed with the leaf chemical analysis, following the protocol of Malavolta (1997), by foliar diagnoses. These samples were taken to a specialized laboratory and passed through 4 steps: decontamination, drying in an incubator with air circulation at $70^{\circ} \mathrm{C}$, grinding and storage. Subsequently, the content of $\mathrm{N}$ and $\mathrm{P}$ in the dry samples was quantified, using de percentage (\%) of these nutrients in the total plant biomass. In total, we performed 12 analyzes ( 3 ponds $\times 4$ collections) for each nutrient $(\mathrm{N}$ and $\mathrm{P}$ ) for both floating and submerged leaves. Results were compared to test whether a differential allocation of $\mathrm{N}$ and $\mathrm{P}$ occur in the different plant vegetative tissues.

To obtain the dry biomass of the structures, we separated 100 ramets from the samples collected of each pond. The collected plants were washed and the structures of each ramet separated in laboratory (floating leaves, submerged leaf, buds and sporocarps). After the separation, the structures were dried at $60^{\circ} \mathrm{C}$ during $48 \mathrm{~h}$ until reaching constant weight, and then, the dry biomass was weighted.

\subsection{Data analyses}

We used the Spearman correlation to verify if the biomass allocation of $S$. auriculata structures (vegetative and reproductive) was associated with the $\mathrm{N}$ and $\mathrm{P}$ concentration in the plant, separately. We used the chemical analysis from the floating leaves and the submerged leaf and we added to obtain the concentration of $\mathrm{N}$ and $\mathrm{P}$ in the whole plant. The biomass of these structures was the dependent variable, while the concentrations of $\mathrm{N}$ and $\mathrm{P}$ in the plant were the independent variables.

To test if differential allocation (trade-off) of $\mathrm{N}$ and $\mathrm{P}$ concentration occur between floating and submerged leaves (shoot/root) we also used the Spearman correlation. All statistical analyses were performed using the SYSTAT 9.0.

\section{Results}

The $\mathrm{N}$ and $\mathrm{P}$ concentrations in water for each sampled pond during the dry and flooding periods are presented in Table 1. The concentrations of $\mathrm{N}$ and $\mathrm{P}$ in these ponds were considered low during all the period of collection $(<20 \mathrm{mg} / \mathrm{L}$ of nitrogen and $<2 \mathrm{mg} / \mathrm{L}$ of phosphorus) (Vollenweider and Kerekes, 1981; Al-Hamdani and Sirna, 2008).

The values of $\mathrm{N}$ and $\mathrm{P}$ concentration in specimens of $S$. auriculata seasonally collected in three ponds are presented in Table 2. The $\mathrm{N}$ concentration in $S$. auriculata tissues showed similar values through the collections, except for the Jacaré pond that presented large differences between the float and the dry periods. To the P concentration, the first collection in the rainy period (February) showed the higher concentrations values in the plant tissues. Probably, the change of periods did not influence the $\mathrm{N}$ and $\mathrm{P}$ concentration in the plant.

Table 1. Analyzes of nitrogen and phosphorus concentrations $(\mathrm{mg} / \mathrm{L})$ in the Cavalo pond, Atola pond, and Jacaré pond, in all collections (February, March, August, September).

\begin{tabular}{ccccc}
\hline \multirow{2}{*}{ Ponds } & \multicolumn{4}{c}{ N concentration $(\mathbf{m g} / \mathbf{L})$} \\
\cline { 2 - 4 } & February & March & August & September \\
\hline Cavalo & 0.03 & 0.56 & 1.00 & 1.00 \\
Atola & 0.10 & 1.12 & 0.80 & 0.90 \\
Jacaré & 0.01 & 2.80 & 0.50 & 0.50 \\
\hline & \multicolumn{4}{c}{ P concentration $\mathbf{( m g / L )}$} \\
\cline { 2 - 4 } & February & March & August & 0.30 \\
Cavalo & 0.08 & 0.70 & 0.50 & 0.20 \\
Atola & 0.01 & 0.20 & 0.30 & 0.08 \\
\hline
\end{tabular}


Table 2. Nitrogen and phosphorus concentrations in S. auriculata (\% plant dry biomass) collected in the Cavalo pond, Atola pond, and Jacaré pond, in all collections (February, March, August, September).

\begin{tabular}{ccccc}
\hline \multirow{2}{*}{ Ponds } & \multicolumn{4}{c}{ N concentration (\%) } \\
\cline { 2 - 5 } & February & March & August & September \\
\hline Cavalo & 2.21 & 1.66 & 1.85 & 1.74 \\
Atola & 2.35 & 2.03 & 2.75 & 2.44 \\
Jacaré & 1.6 & 1.23 & 2.40 & 2.5 \\
\hline & \multicolumn{4}{c}{ P concentration (\%) } \\
\hline Cavalo & February & March & August & September \\
Atola & 0.98 & 0.12 & 0.11 & 0.21 \\
Jacaré & 0.94 & 0.13 & 0.12 & 0.26 \\
\hline
\end{tabular}

Table 3. Spearman correlation between N concentration in plant and the structures biomass of $S$. auriculata (Sporocarps - S; Buds - B; Floating leaves - FL; Submerged leaves - SL).

\begin{tabular}{ccc}
\hline Variables & $\mathbf{r}$ & $\boldsymbol{P}$ \\
\hline S & 0.23 & 0.04 \\
B & 0.28 & 0.02 \\
FL & -0.22 & $<0.001$ \\
SL & 0.22 & $<0.001$ \\
\hline
\end{tabular}

Table 4. Spearman correlation between $\mathrm{P}$ concentration in plant and the structures biomass of $S$. auriculata (Sporocarps-S; Buds-B; Floating leaves-FL; Submerged leaves - SL).

\begin{tabular}{ccc}
\hline Variables & $\mathbf{r}$ & $\boldsymbol{P}$ \\
\hline $\mathrm{S}$ & -0.03 & 0.8 \\
$\mathrm{~B}$ & 0.50 & $<0.001$ \\
$\mathrm{FL}$ & 0.26 & $<0.001$ \\
$\mathrm{SL}$ & 0.23 & $<0.001$ \\
\hline
\end{tabular}

The results with the biomass of each plant structure (sporocarps, buds, floating and submerged leaves) and the $\mathrm{N}$ concentration in the plant are represented in Table 3. All these structures were correlated with the $\mathrm{N}$ concentration in plant $(\mathrm{p}<0.05)$ and presented positive correlation, except for the floating leaves $(\mathrm{r}=-0.22)$. This means that the biomass of all vegetative and reproductive structures is associated with the $\mathrm{N}$ concentration, where an increase of this element is related to an increase of biomass allocation to these parts, except for the floating leaves.

The correlation between the $\mathrm{P}$ concentration in the plant and the biomass of each vegetative and reproductive structure was also significant $(\mathrm{p}<0.05)$, except for the sporocarp biomass $(r=-0.03 ; p>0.8)$ ( see Table 4). This shows that the biomass allocation to the buds, floating and submerged leaves also varies in the same direction that the $\mathrm{P}$ concentration in the plant, except for the sporocarp production.

In the trade-off results, the $\mathrm{N}$ concentration in the floating leaves was positively correlated with $\mathrm{N}$ concentration in the submerged leaf $(\mathrm{r}=0.854 ; \mathrm{p}<0.001)$ (see Figure $1 \mathrm{a})$,
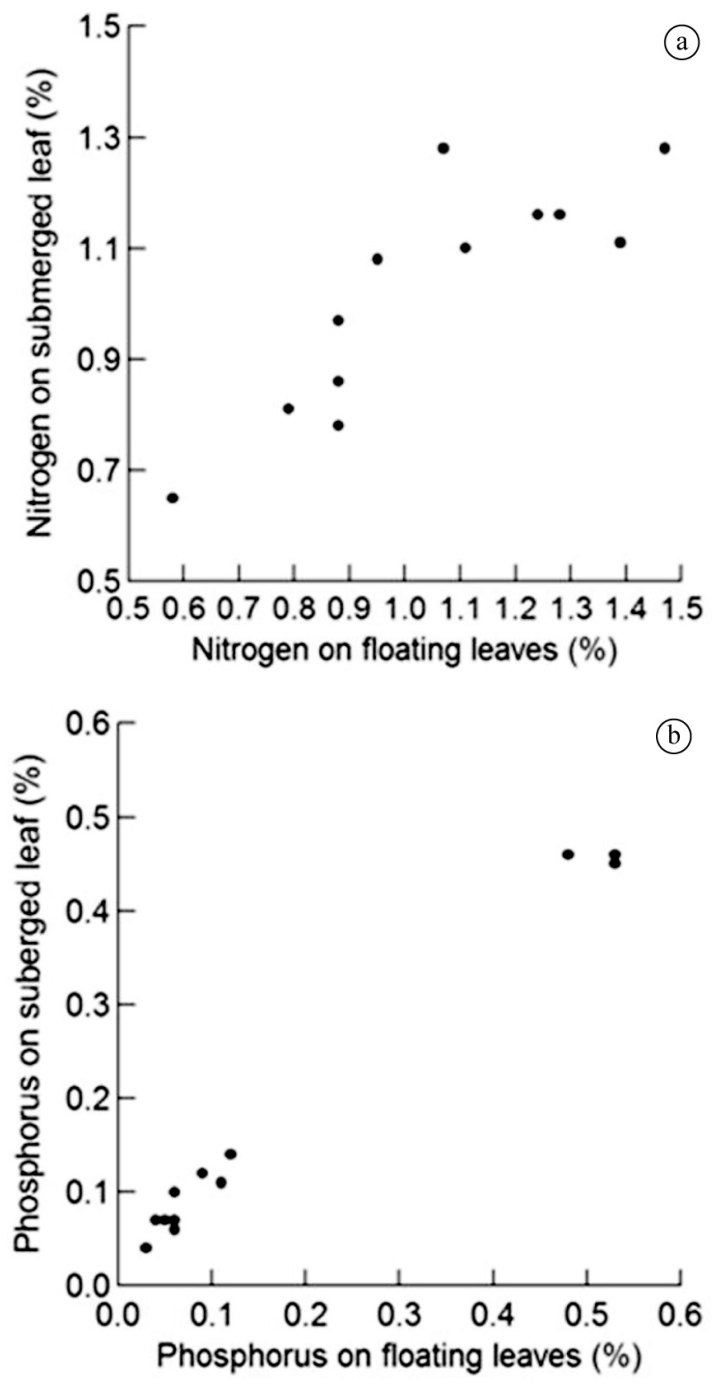

Figure 1. Spearman correlation of: (a) $\mathrm{N}$ concentration (\% dry biomass) between floating leaves and submerged leaf $(\mathrm{r}=0.854 ; \mathrm{p}<0.001)$; and (b) $\mathrm{P}$ concentration ( $\%$ dry biomass) between floating leaves and submerged leaf $(\mathrm{r}=0.995 ; \mathrm{p}<0.001)$, of Salvinia auriculata. 
indicating that the nutrient concentration varies to the same direction in both structures, and that there is not an $\mathrm{N}$ differential allocation occurring between them. The same was observed with the P concentration, where the correlation between floating and submerged leaves was also high $(r=0.995 ; p<0.001)$ (see Figure $1 b)$, what means that there is not a trade-off of $\mathrm{P}$ between shoot and "root" in S. auriculata.

\section{Discussion}

\subsection{Nitrogen and phosphorus concentration in plant}

Our results showed that biomass allocation to the vegetative structures of $S$. auriculata is related to the concentration of $\mathrm{N}$ and $\mathrm{P}$ in the plant, according to our hypothesis. Zhou et al. (2011) shows that the N source affect the biomass allocation to roots and leaves in three aquatic plants, but there are no findings about the $\mathrm{N}$ and $\mathrm{P}$ concentration in the plant affecting the biomass allocation.

$\mathrm{N}$ and $\mathrm{P}$ is one of the most limiting plant nutrients affecting the growth and the nutrient uptake of aquatic plants, despite $\mathrm{P}$ being found in a small amount in the water (Duan et al., 2007, Smith 2014). Cary and Weerts (1983) saw that Salvinia plants can accumulate high concentrations of $\mathrm{N}$, up to $5.5 \%$ of plant dry biomass, and, high concentrations of $\mathrm{P}$, up to $0.7 \%$, according to the availability on the environment. Gauted (1973) also showed that Salvinia have a capacity to store high levels of $\mathrm{P}$, which can be used later when P supplies become limiting. In other aquatic plant, Eichhornia crassipes, there was higher total $\mathrm{P}$ in plant tissues and greater relative growth rates upon treatments with increase $P$ concentration in the water (Kobayashi et al., 2008). Smith (2014), however, showed that the floating plant species used in the study had a nonlinear relationship with the total $\mathrm{N}$ in the field survey. In the present study, it is possible to observe that the $\mathrm{C}$ allocation is associated with the $\mathrm{N}$ and $\mathrm{P}$ concentration in the plant tissue, and not directly with the concentration in water, and this contributes to the $S$. auriculata growth.

No studies with the ideal concentrations of $\mathrm{N}$ and $\mathrm{P}$ in $S$. auriculata tissue could be found. Wersal and Madsen (2011) found around $1.8 \%$ of $\mathrm{N}$ and $0.2 \%$ of $\mathrm{P}$ as critical limiting nutrients for M. aquaticum plant tissues, similar to our observations for $S$. auriculata (Table 1). However, compared with the findings of Julien and Bourne (1986) for S. molesta, our N and P concentrations in S. auriculata tissues were considered low. This could explain the somewhat lower $r$ values in the correlation between the nutrient concentrations and the biomass allocation in our study, but, despite that, biomass allocation of most structures and these nutrients concentration in the plant increase in the same direction.

The correlation between floating leaves biomass and the $\mathrm{N}$ concentration in our results was negative, showing that the high $\mathrm{N}$ concentration values are associated with low values of this structure biomass. Julien and Bourne (1986) showed that a wide variation of $\mathrm{N}$ concentration in plant tissue $(1.74 \%$ for $3.97 \%$ dry weight) has no significant effect on the increase of $S$. molesta biomass (0.091 for $0.101 \mathrm{~g} / \mathrm{g} /$ day). Hilbert (1990) showed different from our results, with a strong linear relationship between plant nitrogen concentration and the fraction of biomass allocated to leaves. Jampeetong et al. (2012b) showed another view, when the external $\mathrm{NH}_{4}{ }^{+}$supply in the water increased, the total $\mathrm{N}$ concentration was significantly reduced in leaves but increased in roots of $S$. cucullata. Studies have documented this kind of tolerance in many free-floating macrophytes (Moseline and Kost, 1993; Caicedo et al., 2000). Therefore, it is not know how this tolerance is related with the total biomass in these structures. In this study, we observed that the $\mathrm{N}$ concentration in plant has negative impact in the biomass allocation to the floating leaves.

For the submerged leaf, both $\mathrm{N}$ and $\mathrm{P}$ concentrations in plant showed a positive correlation and are associated with its biomass. In general, increasing or decreasing P availability in field affects root growth in agricultural plants (Linkohr et al., 2002). Likely, the submerged leaf performs a root function and assimilates most nutrients in the plant (Room, 1990). For the N concentration, Jampeetong and Brix (2009) saw that the "root" morphology of S. natans was affected by the different $\mathrm{N}$ sources and also showed that the $\mathrm{NO}_{3}^{-}$assimilation primarily occurs in the roots and only a small amount is transported to the leaves. Nutrient uptake via leaves in S. cucullata is insignificant compared to root assimilation (Jampeetong et al., 2012a). In our results, it is possible to observe that the "root" biomass is related to the $\mathrm{N}$ and $\mathrm{P}$ concentration.

Regarding the reproductive structures, we saw that the buds were associated with both $\mathrm{N}$ and $\mathrm{P}$ concentrations in the plant. Clonal propagation is stimulated when nutrient availability increase in the environment (Xie et al., 2004), and our results showed that the $\mathrm{N}$ and $\mathrm{P}$ content in the plant tissues also contributes with the buds production. Plants with both sexual and asexual reproduction have the strategy influenced by different nutrient levels (Liu et al., 2009). However, in our study, although the concentration of $\mathrm{N}$ in the plant was associated with the sporocarp production, we found that $\mathrm{P}$ has not influence in this biomass structure. According to Coelho et al. (2005), sporocarps are sexual reproduction structures that are directly connected to the dry condition in the environment, serving as a structure of resistance and dormancy during this stress period. Differently, favorable habitats promote asexual over sexual reproduction (Sakai, 1995; Gardner and Mangel, 1999) and buds are formed with wide nutrient availability (Thompson and Eckert, 2004).

The $\mathrm{N}$ and $\mathrm{P}$ levels incorporated by free-floating macrophytes are usually related to the concentration of these nutrients in the water (Reddy and D'Angelo, 1990), aided by the high capability to uptake nutrients into biomass (Esteves, 1982). Furthermore, in our study we observed that the biomass of Salvinia is associated with the $\mathrm{N}$ and $\mathrm{P}$ concentration in plant. Some studies show that the Salvinia genus is able to develop in environments with low water nutrient concentrations (Benassi and Camargo, 
2000; Thomaz et al., 2006; Rubim and Camargo, 2001). This indicates that Salvinia is probably able to grow in ecosystems with lower $\mathrm{N}$ and $\mathrm{P}$ concentrations in the water, because is capable to uptake great levels of this nutrients in the tissues. But, it is important to consider the increase of pollution in water bodies and how it affects the macrophytes growth. Our results suggested that high levels of $\mathrm{N}$ and $\mathrm{P}$ in the tissues by increases in water eutrophication and, consequently, in nutrient uptake, may result in an increase of biomass of S. auriculata, contributing to its expansion.

\section{2. $N$ and $P$ differential allocation between floating leaves and submerged leaf}

The correlation value of the $\mathrm{N}$ concentration between floating leaves and the submerged leaf was high and positive, showing that there is not a differential allocation (trade-off) of this nutrient between shoot and "root". The same occurs with the $\mathrm{P}$ concentration. Thus, the $\mathrm{N}$ and $\mathrm{P}$ allocation to the submerged leaf does not inhibit the allocation of these nutrients to the floating leaves, and vice versa, at high or low concentrations in the structures. Cedergreen and Madsen (2002) saw that free-floating macrophytes obtain $\mathrm{N}$ and other nutrients directly from the water column through their roots and the underside of their leaves. In the case of $S$. auriculata, $\mathrm{N}$ is also translocated through the development of new ramets (Li and Wang, 2011). In our study, we can observe that the $\mathrm{N}$ and $\mathrm{P}$ removed from the water remain in a balanced way in the plant tissues, without a trade-off between the vegetative structures. Thus, we can predict that $S$. auriculata is able to store $\mathrm{N}$ and $\mathrm{P}$ in both shoot and "root" tissues. Therefore, our data suggests that the balance of $\mathrm{N}$ and $\mathrm{P}$ distribution in the structures of $S$. auriculata, which are essential nutrients for plant biomass allocation, is responsible for the fast rate of new biomass synthesis in short periods of time that typically characterizes the weedy behavior of $S$. auriculata.

\section{Conclusion}

We concluded that the biomass allocation in S. auriculata is related to $\mathrm{N}$ and $\mathrm{P}$ concentration in the plant tissues. The results show that each structure presented a differential direction of biomass according to the nutrient, as the floating leaves that presented a negative correlation with the $\mathrm{N}$ concentration in the plant. Besides of nutrients availability in the water, the plant biomass is directly related to the concentration of $\mathrm{N}$ and $\mathrm{P}$ in plant tissues. Furthermore, we observed that trade-off of $\mathrm{N}$ and $\mathrm{P}$ concentration does not occur between floating leaves and the submerged leaf. We can see that these nutrients are allocated to the "root" in the same way that they are allocated to the shoot. Further studies are still required to understand the physiologic mechanisms driving S. auriculata biomass allocation and the consequence of this allocation to its growth. This information could help find better ways to manage this species in many different environments.

\section{Acknowledgements}

The authors are grateful to Kira Malves and Bárbara Temponi for cooperating in the collections; to Carla Ribas, Marcelo Guimarães and Luciana Madeira da Silva for their valued comments on the manuscript elaboration. The manuscript was partially produced during the course PEC533 - Scientific Publication in Ecology, Pós-Graduação em Ecologia Aplicada from Universidade Federal de Lavras program. This study was supported by FAPEMIG.

\section{References}

AL-HAMDANI, S.H. and SIRNA, C.B., 2008. Physiological responses of Salvinia minima to different Phosphorus and Nitrogen concentrations. American Fern Journal, vol. 98, no. 2, pp. 71-82.

AMERICAN PUBLIC HELTH ASSOCIATION - APHA, AMERICAN WATER WORKS ASSOCIATION - AWWA, WATER ENVIRONMENT FEDERATION - WEF, 2005. Standard methods for the examination of water and wastewater. 21 st ed. Washington: APHA.

BARKO, J.W. and SMART, R.M., 1986. Sediment-related mechanisms of growth limitation in submersed macrophytes. Ecology, vol. 67, pp. 1328-1340.

BENASSI, R.F. and CAMARGO, A.F.M., 2000. Avaliação do processo competitivo entre duas espécies de macrófitas aquáticas flutuantes. Revista de Iniciação Científica, vol. 1, pp. 59-66.

BORNETTE, G. and PUIJALON, S., 2011. Response of aquatic plants to abiotic factors: a review. Aquatic Sciences, vol. 73, pp. 1-14.

CAICEDO, J.R., VAN DER STEEN, N.P., ARCE, O. and GIJZEN, H.J., 2000. Effect of total ammonia nitrogen concentration and $\mathrm{pH}$ on growth rates of duckweed (Spirodela polyrrhiza). Water Research, vol. 34, pp. 3829-3835.

CAMARGO, A.F.M., PEZZATO, M.M. and HENRY-SILVA, G.G., 2003. Fatores limitantes à produção primária de macrófitas aquáticas. In: THOMAZ, S.M. and BINI, LM., eds. Ecologia e manejo de macrófitas aquáticas. Maringá: EDUEM.

CARY, P.R. and WEERTS, P.G.J., 1983. Growth of Salvinia molesta as affected by water temperature and nutrition. I. Effects of nitrogen level and nitrogen compounds. Aquatic Botany, vol. 16, pp. 163-172.

CEDERGREEN, N. and MADSEN, T.V., 2002. Nitrogen uptake by the floating macrophyte Lemna minor. The New Phytologist, vol. 155 , pp. 285-292.

CHAPIN 3RD, F.S., CALLAGHAN, T.V., BERGERON, Y., FUKUDA, M., JONHNSTONE, J.F., JUDAY, G. and ZIMOV, S., 2004. Global change and the boreal forest: thresholds, shifting states, or gradual change? Ambio, vol. 33, no. 6, pp. 361-365. PMid:15387075.

COELHO, F.F., LOPES, F.S. and SPERBER, C.F., 2005. Persistence strategy of Salvinia auriculata Aublet in temporary ponds of Southern Pantanal, Brazil. Aquatic Botany, vol. 81, pp. 343-352.

DE LA SOTA, E.R., 1962. Contributio al conocimento de las Salviniaceae neotropicales. II. Salvinia auriculata Aublet. Darwiniana, vol. 12, pp. 499-513.

DUAN, Y.H., ZHANG, Y.L., YE, L.T., FAN, X.R., XU, G.H. and SHEN, Q.R., 2007. Responses of rice cultivars with different 
nitrogen use efficiency to partial nitrate nutrition. Annals of Botany, vol. 99, no. 6, pp. 1153-1160. PMid:17428833.

ELLIS, J.B., SHUTES, R.B., REVITT, D.M. and ZHANG, T.T., 1994. Use of macrophytes for pollution treatment in urban wetlands. Resources, Conservation and Recycling, vol. 11, pp. 1-12.

ESTEVES, F.A., 1982. Biomass and analysis of the major inorganic components of floating aquatic macrophyte (Eichhornia crassipes) (mart). Solms) in six reservoirs of São Paulo State (Brasil). Ciencia e Cultura, vol. 34, no. 9, pp. 1196-1200.

ESTEVES, F.A., 2011. Fundamentos de limnologia. 3rd ed. Rio de Janeiro: Interciência Ltda.

GARDNER, S.N. and MANGEL, M., 1999. Modeling investments in seeds, clonal offspring, and translocation in a clonal plant. Ecology, vol. 80, pp. 1202-1220.

GAUTED, J.J., 1973. Growth of a floating aquatic weed, Salvinia, under standard conditions. Hydrobiologia, vol. 41, pp. 77-106.

GOPAL, B., 1990. Indian subcontinent and the aquatic habitats. In GOPAL, B. Ecology and management of aquatic vegetation in the Indian subcontinent. Dordrecht: Kluwar Academic Publishers.

GRIME, J.P., 1979. Plant strategies and vegetation processes. Chichester: Wiley.

HILBERT, D.W., 1990. Optimization of plant root: shoot ratios and internal nitrogen concentration. Annals of Botany, vol. 66, pp. 91-99.

HUSZAR, V.L.M., CARACO, N.F., ROLAND, F. and COLE, J., 2006. Nutrientchlorophyll relationships in tropical-suptropical lakes: do temperate models fit? Biogeochemistry, vol. 79, pp. 239-250.

IWASA, Y. and ROUGHGARDEN, J.D., 1984. Shoot:root balance of plants: optimal growth of a system with many vegetative organs. Theoretical Population Biology, vol. 25, pp. 78-105.

JAMPEETONG, A. and BRIX, H., 2009. Nitrogen nutrition of Salvinia natans: effects of inorganic nitrogen form of growth, morphology, nitrate reductase activity and uptake kinetics of ammonium and nitrate. Aquatic Botany, vol. 90, pp. 67-73.

JAMPEETONG, A., BRIX, H. and KANTAWANICHKUL, S., 2012a. Effects of inorganic nitrogen forms on growth, morphology, nitrogen uptake capacity and nutrient allocation of four tropical aquatic macrophytes (Salvinia cucullata, Ipomoea aquatica, Cyperus involucratus and Vetiveria zizanioides). Aquatic Botany, vol. 97 , pp. 10-16.

JAMPEETONG, A., BRIX, H. and KANTAWANICHKUL, S., 2012b. Response of Salvinia cucculata to high $\mathrm{NH}_{4}^{+}$concentrations at laboratory scales. Ecotoxicology and Environmental Safety, vol. 79, pp. 69-74. PMid:22195762.

JULIEN, M.H. and BOURNE, A.S., 1986. Compensatory branching and changes in nitrogen content in the aquatic weed Salvinia molesta in response to disbudding. Oecologia, vol. 70, pp. 250-257.

JULIEN, M.H., CENTER, T.D. and TIPPING, P.W., 2002. Floating fern (Salvinia). Biological control of invasive plants in the eastern United States. USDA Forest Service Publication, vol. 4, pp. 17-32.

KOBAYASHI, J.T., THOMAZ, S.M. and PELICICE, F.M., 2008. Phosphorus as a limiting factor for Eichhornia crassipes growth in the upper Paraná River Floodplain. Wetlands, vol. 28, pp. 905-913.
LI, W. and WANG, J., 2011. Influence of light and nitrate assimilation on the growth strategy in clonal weed Eichhornia crassipes. Aquatic Ecology, vol. 45, pp. 1-9.

LINKOHR, B.I., WILLIAMSON, L.C., FITTER, A.H. and LEYSER, H.M., 2002. Nitrate and phosphate availability and distribution have different effects on root system architecture of Arabidopsis. The Plant Journal, vol. 29, no. 6, pp. 751-760. PMid:12148533.

LIU, K., THOMPSON, F.L. and ECKERT, C.G., 2009. Trade-off between sexual and asexual reproduction in a monoecious species Sagittaria pygmaea (Alismataceae): the effect of different nutrient levels. Plant Systematics and Evolution, vol. 277, pp. 61-65.

LOVETT DOUST, J., 1989. Plant reproductive strategies and resources allocation. Trends in Ecology \& Evolution, vol. 4, no. 8, pp. 230-234. PMid:21227356.

LUO, W., JIANG, Y., LÜ, X., WANG, X., LI, M.-H., BAI, E., HAN, X. and XU, Z., 2013. Patterns of plant biomass allocation in temperate grasslands across a $2500-\mathrm{km}$ Transect in Northern China. PLoS One, vol. 8, no. 8, pp. e71749. PMid:23977135.

MADSEN, J.D., CHAMBERS, P.A., JAMES, W.F., KOCH, E.W. and WESTLAKE, D.F., 2001. The interaction between water movement, sediment dynamics and submerged macrophytes. Hydrobiologia, vol. 444, pp. 71-84.

MALAVOLTA, E., 1997. Avaliação do estado nutricional das plantas. 2nd ed. Piracicaba: Potafos.

MARSCHENER, H., 1995. Mineral nutrition of higher plants. 2nd ed. London: Academic, 889 p.

MARTÍN, L.T., PEZESHKI, S.R. and SHIELDS JUNIOR, F.D., 2005. Soaking treatment increases survival of black willow posts in a large-scale field study. Ecological Research, vol. 23, pp. 95-98.

MCFARLAND, D.G., NELSON, L.S., GRODOWITZ, M.J., SMART, R.M. and OWENS, C.S., 2004. Salvinia molesta D.S. Mitchell (Giant Salvinia) in the United States: a review of species ecology and approaches to management Washington:. Engineer Research and Development Center, p. 1-33.

MOSELINE, E.B.I. and KOST, D., 1993. Different ammoniumion uptake, metabolism and detoxification efficiencies in two Lemnaceae. Planta, vol. 189, pp. 167-173

OLSON, E.J., ENGSTROMA, E.S., DOERINGSFELD, M.R., , BELLIG , B., 1999. The abundance and distribution of macroinvertebrates in relation to macrophyte communities in Swan Lake, Nicollet County, MN. St. Peter: Department of Natural Resources.

PANIGATTI, M.C. and MAINE, M.A., 2003. Influence of nitrogen species $\left(\mathrm{NH}_{4}^{+}\right.$and $\mathrm{NO}_{3}^{-}$on the dynamics of $\mathrm{P}$ in water-sedimentSalvinia herzogii systems. Hydrobiologia, vol. 492, pp. 151-157.

PETERSON, S.B. and TEAL, J.M., 1996. The roles of plants in ecologically engineered wastewater treatment systems. Ecological Engineering, vol. 6, pp. 137-148.

PORTAL MEIO AMBIENTE, 2014 [viewed 23 January 2014]. Bacia hidrográfica do Rio Grande. Belo Horizonte: IGAM [online]. Available from: http://www.igam.mg.gov.br/index. php?option $=$ com_content $\&$ task $=$ view\&id $=150 \&$ Itemid $=140$

RAN, N., AGAMI, M. and ORON, G., 2004. A pilot study of constructed wetlands using duckweed (Lemna gibba L.) for treatment of domestic primary effluent in Israel. Water Research, vol. 38, no. 9, pp. 2240-2248. PMid:15142784. 
RAST, W. and THORNTON, J.A., 1996. Trends in eutrophication research and control. Hydrological Processes, vol. 10, no. 2, pp. 295-313.

REDDY, K.R. and D'ANGELO, E.M., 1990. Biomass yield and nutrient removal by water hyacinth (Eichhornia crassipes) as influenced by harvesting frequency. Biomass, vol. 21, pp. 27-42.

ROOM, P.M., 1990. Ecology of a simple plant-herbivore system: biological control of Salvinia. Trends in Ecology \& Evolution, vol. 5, no. 3, pp. 74-79. PMid:21232327.

RUBIM, M.A.L. and CAMARGO, A.F.M., 2001. Taxa de crescimento específico da macrófita aquática Salvinia molesta Michell em um braço do Rio Preto, Itanhaém, São Paulo. Acta Limnologica Brasiliensia, vol. 13, no. 1, pp. 75-83.

SAKAI, S., 1995. Optimal resource allocation to vegetative and sexual reproduction of a plant growing in a spatially varying environment. Journal of Theoretical Biology, vol. 175, pp. 271-282.

SCULTHORPE, C.D., 1985. The biology of aquatic vascular plants. London: Edward Arnold.

SILVA, L.F., 2010. Estequiometria ecológica da interação trófica consumidor - perifiton: uma abordagem experimental. Rio de Janeiro: Universidade Federal do Rio de Janeiro, 133 p. Masters Dissertation in Ecology.

SMITH, S.D.P., 2014. The roles of nitrogen and phosphorus in regulating the dominance of floating and submerged aquatic plants in a field mesocosm experiment. Aquatic Botany, vol. 112, pp. 1-9.

STANSFIELD, J.H., PERROW, M.R., TENCH, L.D., JOWITT, A.J.D., TAYLOR, A.A.L., 1997. Submerged macrophytes as refuges for grazing Cladocera against fish [-3pt]predation: observations on seasonal changes in relation to macrophyte cover and predation pressure. Hydrobiologia, vol. 342, no. 0, pp. 229-240.

STEARNS, S.C., 1992. The evolution of life histories. London. Oxford University Press.

SULTAN, S.E., 2000. Phenotypic plasticity for plant development, function and life-history. Trends in Plant Science, vol. 5, no. 12, pp. 537-542. PMid:11120476.
THOMAZ, S.M., PAGGIORO, T.A., BINI, L.M. and MURPHY, K.J., 2006. Effects of reservoir drawdown on biomass of three species of aquatic macrophytes in a large sub-tropical reservoir (Itaipu, Brazil). Hydrobiologia, vol. 570, pp. 53-59.

THOMPSON, F.L. and ECKERT, C.G., 2004. Trade-offs between sexual and clonal reproduction in an aquatic plant: experimental manipulations vs. phenotypic correlations. Journal of Evolutionary Biology, vol. 17, no. 3, pp. 581-592. PMid:15149401.

VOLLENWEIDER, R.A. and KEREKES, J.J., 1981. Background and summary results of the OECD cooperative program on eutrophication. In: ENVIRONMENTAL PROTECTION AGENCY. Restoration of Lakes and Inland Waters. Washington: EPA, 2536. EPA/ 440/5-81-010.

WEINER, J., 2004. Allocation, plasticity and allometry in plants. Elsevier GmbH, vol. 6, no. 4, pp. 207-215.

WERSAL, R.M. and MADSEN, J.D., 2011. Influences of water column nutrient loading on growth characteristics of the invasive aquatic macrophyte Myriophyllum aquaticum (Vell.) Verdc. Hydrobiologia, vol. 665, pp. 93-105.

WILSON, J.B., 1988. A review of evidence on the control of shoot: root ratio, in relation to models. Annals of Botany, vol. 61, pp. 433-449.

WOLFF, G., PEREIRA, G.C., CASTRO, E.M., LOUZADA, J. and COELHO, F.F., 2012. The use of Salvinia auriculata as a bioindicator in aquatic ecosystems: biomass and structure dependent on the cadmium concentration. Brazilian Journal of Biology = Revista Brasileira de Biologia, vol. 72, no. 1, pp. 71-77. PMid:22437387.

XIE, Y., WEN, M., YU, D. and LI, Y., 2004. Growth and resource allocation of water hyacinth as affected by gradually increasing nutrient concentrations. Aquatic Botany, vol. 79, pp. 257-266.

ZHOU, X., WANG, G. and YANG, F., 2011. Characteristics of growth, nutrient uptake, purification effect of Ipomoea aquatic, Lolium multiflorum and Sorghum sudanense grown under different nitrogen levels. Desalination, vol. 273, pp. 366-374. 